\title{
A study of morbidity pattern in Misgav Ladach technique of caesearean section
}

\author{
Nitin Kshirsagar, Kruthika R. Sajjan, Sanjay Patil, Basavaraj Nagur*
}

Department of Obstetrics and Gynecology, KIMS University, Karad, Maharashtra, India

Received: 07 April 2016
Accepted: 07 May 2016

\author{
*Correspondence: \\ Dr. Basavaraj Nagur, \\ E-mail: sachin.nagur@gmail.com
}

Copyright: (c) the author(s), publisher and licensee Medip Academy. This is an open-access article distributed under the terms of the Creative Commons Attribution Non-Commercial License, which permits unrestricted non-commercial use, distribution, and reproduction in any medium, provided the original work is properly cited.

\begin{abstract}
Background: There has been progressive increase in C-section (CS) rate globally since last 10 years. Issues related to maternal choice, Mode of delivery for non-cephalic presentation at term, vaginal delivery after previous scar have been the focus of attention. The objective of the study was to determine whether Misgav Ladach caesarean section technique offers benefits over Traditional Method of caesarean section with regards to Duration of surgery, Time taken for abdominal entry, Total operation time, Amount of blood loss and Postoperative morbidity.

Methods: A randomized control study was carried out on 460 patients who underwent Caesarean section at Krishna hospital, Karad, Maharashtra, India between November 2013 to June 2015.

Results: 460 cases of caesarean section admitted to Krishna institute of medical sciences, karad during the period of November 2013 to June 2015 were studied with respect of clinical pattern, majority of the cases who underwent, caesarean section by both the methods were in the age group of 21-25 years. The main indication for caesarean section was fetal distress. Fetal distress accounts for 29\% in Misgav Ladach method and $31 \%$ in traditional method, failed induction accounts for $6 \%$ in Misgav Ladach and $8 \%$ in traditional method. The total operation time was 31 min average in Misgav Ladach and $37 \mathrm{~min}$ in traditional group. The mean blood loss for the Misgav Ladach group was $486 \mathrm{ml}$ and $521 \mathrm{ml}$ for the traditional group, which was significantly different $(\mathrm{p}<0.001)$. The postoperative morbidity due to fever was $4 \%$ in the both groups.

Conclusions: Substantial reductions in operating time and blood loss were noted in the study, which may benefit the women in reducing the exposure time to anesthesia.
\end{abstract}

Keywords: Misgav Ladach technique, Traditional method technique, Morbidity

\section{INTRODUCTION}

Misgav Ladach method of caesarean has been named by Dr. Michael stark after the hospital in Jerusalem. It was studied first in 1983. The main causes for rise in Csection rate is concern about maternal mortality and neonatal morbidity. Modern obstetric practice for medical, social, economic and legal reasons is witnessing an increase in the primary $\mathrm{C}$-section rate everywhere.

There are many way to approach the abdominal delivery of the fetus through Pfannensteil to, midline and transverse incision to Joel cohens. ${ }^{1}$ Pfannensteil incision is the method of choice in many hospitals. Lower uterine segment transverse incision is most commonly performed, Described by Kerr in $1926 .{ }^{2}$ The rate of cesarean section is raising in many countries over past 10 years. Many factors responsible for the raise have been put forward in the international journal like reduced parity, older primipara, use of electronic fetal monitoring, delivery of breech by caesarean section, less use of forceps, fear of litigation, high socioeconomic status. ${ }^{3}$

The main features of our study Misgav Ladach technique of caesarean section are transverse Joen Cohen incision for opening the abdomen, suturing uterine incision in one layer and non-closure of visceral and parietal peritoneum. 


\section{METHODS}

A randomised control study was carried out on 460 patients who underwent Caesarean section at Krishna hospital, Karad, Maharashtra, India between November 2013 to June 2015.

They were randomised into 2 groups on the basis of their Inpatient department (IPD) no. All patients with even IPD number were put in Misgav Ladach group. All patients with Odd IPD number were put in traditional method group.

\section{Inclusion criteria}

- $\quad$ Patient undergoing primary CS

- $\quad$ Singleton pregnancy

\section{Exclusion criteria}

- Previous CS

- Obstructed Labour

- Bleeding Disorder

- $\quad$ Severe Anaemia ( $<7 \mathrm{gm} \%)$

- Placenta Previa

- Abruption Placenta

- Rupture Uterus

- Previous Abdominal Surgery

- Multiple Pregnancy

- Intrapartum Febrile Illness

Patients requiring primary caesarean section were included in study. After taking a through history and complete general and abdominal examination was done, written informed consent was taken

Patients were divided into 2 groups according to the IPD number.

Even - Misgav Ladach group

Odd - traditional method group.

Bladder was routinely catheterised before surgery. Prophylactic single dose of antibiotics injection Taxim $1 \mathrm{gm}$ intravenously was given half an hour prior to surgery. The choice of anaesthesia was governed by anaesthetist. On $3^{\text {rd }}$ post-operative day repeat hemoglobin levels were done.

\section{RESULTS}

460 cases of caeasarean section admitted to Krishna institute of medical sciences, Karad, Maharashtra, India during the period of November 2013 to June 2015 were studied with respect of clinical pattern.

In our study majority of the cases who underwent, caesarean section by both the methods were in the age group of 21-25 years (Table 1). In the present series the maximum number of patients who underwent primary caesarean section either by Misgav Ladach method (80\%) or by traditional method $(83.91 \%)$ was primigravida. In the present study the main indication for caesarean section was foetal distress. Fetal distress accounts for $29 \%$ in Misgav Ladach method and $31 \%$ in traditional method, failed induction accounts for $6 \%$ in Misgav Ladach and $8 \%$ in traditional method (Table 2).

Table 1: Age group.

\begin{tabular}{|lll|}
\hline Age (Yrs) & $\begin{array}{l}\text { Misgav Ladach } \\
\text { method }\end{array}$ & $\begin{array}{l}\text { Traditional } \\
\text { method }\end{array}$ \\
\hline$<20$ & 44 & 46 \\
\hline $21-25$ & 124 & 135 \\
\hline $26-30$ & 54 & 42 \\
\hline $31-35$ & 6 & 6 \\
\hline $36-40$ & 1 & 1 \\
\hline$>45$ & 1 & 0 \\
\hline Total & 230 & 230 \\
\hline
\end{tabular}

Table 2: Indication for caesarean section.

\begin{tabular}{|lll|}
\hline Indications & $\begin{array}{l}\text { Misgav } \\
\text { Ladach } \\
\text { group }\end{array}$ & $\begin{array}{l}\text { Traditional } \\
\text { method }\end{array}$ \\
\hline Fetal distress & 67 & 72 \\
\hline Non-progress & 35 & 36 \\
\hline Breech & 34 & 21 \\
\hline demand for LSCS & 35 & 38 \\
\hline Oligohydramnios & 14 & 13 \\
\hline Failure of induction & 14 & 20 \\
\hline PROM & 13 & 9 \\
\hline Precious pregnancy & 8 & 4 \\
\hline Sever pre-eclampsia & 4 & 5 \\
\hline Transverse lie & 3 & 2 \\
\hline CPD & 2 & 8 \\
\hline brow & 1 & 2 \\
\hline Total & 230 & 230 \\
\hline
\end{tabular}

In our study, the time taken to enter the abdomen was 1.4 minutes average in Misgav Ladach method and $2.4 \mathrm{~min}$ average in traditional method. The total operation time was $31 \mathrm{~min}$ average in Misgav Ladach and $37 \mathrm{~min}$ in traditional group (Table 3). The significant difference of postoperative Hemoglobin $(\mathrm{Hb} \%)$ was noted between the two group in our study (Table 4), The mean blood loss for the Misgav Ladach group was $486 \mathrm{ml}$ and $521 \mathrm{ml}$ for the traditional group, which was significantly different $(\mathrm{p}<0.001)$.

$5 \%$ in the Misgav Ladach group had lateral extension of the uterine incision vs. $3 \%$ in the traditional group. $2 \%$ in the Misgav Ladach vs. $4 \%$ in the traditional group developed atonic PPH intraoperatively. 
The postoperative morbidity due to fever was $4 \%$ in the both groups. $5 \%$ of cases in Misgav Ladach group had wound infection vs $6 \%$ in traditional method rest all had healthy wound at suture removal. There were no statistically significant differences in the postop morbidity between the two groups in our study.

Table 3: Time taken to enter the abdomen.

\begin{tabular}{|llllll|}
\hline & Misgav Ladach method & Traditional method & Difference & $t$ & P-value \\
\hline Mean $\pm \mathrm{Sd}$ & $1.48 \pm 0.16 \mathrm{~min}$ & $2.46 \pm 0.27 \mathrm{~min}$ & $0.58 \mathrm{~min}$ & 47.21 & $<0.001$ (HS) \\
\hline
\end{tabular}

Table 4: Post-operative $\mathrm{Hb} \%$ difference.

\begin{tabular}{|llllll|} 
& Misgav Ladach method & Traditional method & Difference & $t$ & P-value \\
Mean \pm Sd & $0.97 \pm 0.22$ & $1.23 \pm 0.27$ & 0.26 & 11.03 & $<0.001($ HS $)$ \\
\hline
\end{tabular}

8\% in Misgav Ladach group and 9\% in traditional group had neonatal jaundice, which required phototherapy. $7 \%$ in the traditional group had severe birth asphyxia in Misgav Ladach group it was $6 \%$ and $4 \%$ in Misgav Ladach group had meconium aspiration in traditional also it was $4 \%$. Thus there was no significant difference in the two groups in terms of perinatal morbidity.

\section{DISCUSSION}

Caesarean section is the most frequently performed major surgery in Obstetrics. The number and hence the rate of caesarean deliveries has been progressively increasing in recent years.

Though the number of cases studied is small, an earnest attempt is made to correlate these results with other parallel studies in the literature.

The range of age in our study in the control group was 18-35 years and 18-30 years in the study group. Agarwal Seema et al showed a range of 18-39 years in the control group and 18-32 years in the study group which is comparable to our study. ${ }^{4}$

Sadhna $\mathrm{G}$ et al reported $83 \%$ in study group and $72 \%$ in control respectively were primigravidas in their study, which is comparable with the present study.

In Majority of the cases in Misgav Ladach group the time taken for surgery was 31-35 $\mathrm{min}$ and in traditional method it was 36-40 min. A study done by Sharma A and et al showed that time taken to deliver the baby was 1.8 min in Misgav Ladach group and in traditional method it was 4 min total time for surgery in Misgav Ladach group was $23 \mathrm{~min}$ and in traditional method it was 35 min. ${ }^{5}$

In a study done by Bhattacharya Misgav Ladach method showed fall of $\mathrm{Hb} \%$ of $1 \mathrm{gm} \%$ and traditional method showed a fall of $1.5 \mathrm{gm} \%$ which is comparable to our study, which showed a fall of $0.8 \mathrm{gm} \%$ in the study group and $1.2 \mathrm{gm} \%$ in the control group. ${ }^{6}$ Hershey and Quilligan also found that exteriorization of uterus was associated with smaller decrease in postoperative haematocrit than if was sutured in situ. ${ }^{7}$

$52 \%$ vs. $35 \%$ in the two groups had blood loss between $400 \mathrm{ml}$ to $500 \mathrm{ml}$ in the Misgav Ladach and traditional groups respectively. Darj E and Nordstrom ML compared the blood loss in Misgav Ladach technique to that in traditional method in 50 cases. The amount of blood loss differed significantly with $448 \mathrm{ml}$ and $608 \mathrm{ml}$ in the two groups' respectively. ${ }^{8}$

There were no statistically significant differences in the postop morbidity between the two groups in our study. In a study by Hudic I show that the febrile morbidity is less in Misgav Ladach group than compared to traditional method. ${ }^{9}$

There was no significant difference in the two groups in terms of perinatal morbidity. According to Cochrane review there was no difference in neonatal NICU admission.

$5 \%$ in the Misgav Ladach group had lateral extension of the uterine incision vs $3 \%$ in the traditional group. $2 \%$ in the Misgav Ladach vs $4 \%$ in the traditional group developed atonic Post-partum hemorrhage intraoperatively. Rajurkar and Sood conducted a study on 350 cases of caesarean section by the traditional method and reported the following major intraoperative complications. $4.9 \%$ cases had extension of incision, 11.95 cases had haemorrhage and 1.2 cases required obstetric hysterectomy. ${ }^{10}$

\section{CONCLUSION}

Caesarean operation is one of the oldest operations done by the obstetricians. The technique of caesarean operation has been modified from time to time. The Misgav Ladach method is a simple speedy, yet safe technique. Substantial reductions in operating time and blood loss were noted in the study, which may benefit the women in reducing the exposure time to anesthesia and infective morbidity. 
Unnecessary steps such as suturing the peritoneal layers are omitted. Rapid and complete healing is ensured with less long and short term complications. Women delivered by this technique regained control and recovered rapidly and were better able to breast feed and care for their new born. Joel Cohen incision for opening the abdomen, suturing the uterus in single layer and non-closure of visceral and parietal peritoneum form the major modification of this technique. The eight layers of suturing in the traditional technique as advocated by Kerr have been reduced to three with seemingly no loss of strength in the subsequent scar and less adhesion and scar tissue formation.

There is conflicting opinion amongst obstetricians as to whether one should routinely exteriorize the uterus to facilitate repair during caesarean section or alternatively, suture the uterine incision in situ. The benefits of MisgavLadach method, which has minimal blood loss, lees pain post-operatively and quicker recovery, are all a byproduct of doing the east harm during surgery and removing every unnecessary step. This method is appealing for its simplicity, ease of execution and its time saving advantage. Wellbeing of the neonate as evidenced by the APGAR scores at birth, morbidity and perinatal mortality was similar as compared to the traditional method.

\section{ACKNOWLEDGEMENTS}

Authors would like to thanks technical staff of OBGY department KIMS University.

Funding: No funding sources Conflict of interest: None declared

Ethical approval: The study was approved by the Institutional Ethics Committee

\section{REFERENCES}

1. Stark M, Finkel PR. Comparison between the Joel Cohen and Pfannenstiel incisions in caesarean section. Eur J Obstet Gynecol. Reprod Biol. 1994;53:121-2.

2. Kerr JIVIM. The technique of caesarean section with special reference to the lower uterine segment incision. Am J Obstet. Gynecol. 1926;12:729-34.

3. Goldman G, Pinrault R, Bllodran H. Factors influence the practice of VBAC. AMJ of Public Health. 1993:1104-8.

4. Mahmud G, Tobassum A. Comparative analysis of MMC and convention caesarean section. Ann Pak Med Sci. 2013;9(3):153-8.

5. Sharma A, Singh M. Comparative between modified Misgav Ladach technique and pfannenstiel method of lower segment caesarean section, national journal of medical research. 2013;3(3):286-8.

6. Bhattacharyya N. Our experience of modified. Misgav Ladach caesarean section. FOGS. 1998;48(1):76-80.

7. Hershey DW, Quilligan EJ. Extra abdominal exteriorization at caesarean section. Obstet Gynecol. 1978;52(2):189-92.

8. Darj E, Nordstorm ML. The Misgav Ladach method for caesarean section compared to the Pfannenstiel method. Acta Obstet Gynecol Scand. 1999;78(1):37.

9. Hudić I, Bujold E, Fatušić Z, Skokić F, Latifagić A, Kapidžić M. The Misgav-Ladach method of cesarean section: a step forward in operative technique in obstetrics. Arch Gynecol Obstet. 2012;286(5):1141-6.

10. Rajurkar K, Sood M. Maternal morbidity and mortality in caesarean section: a clinical analysis of 350 cases. J Obst Gynae India. 1987;42:823.

Cite this article as: Kshirsagar N, Sajjan KR, Patil S, Nagur B. A study of morbidity pattern in Misgav Ladach technique of caesearean section. Int J Reprod Contracept Obstet Gynecol 2016;5:1925-8. 